University for Business and Technology in Kosovo

UBT Knowledge Center

UBT International Conference

2015 UBT International Conference

Nov 7th, 9:00 AM - 5:00 PM

\title{
New configurations of housing facilities developed in height. Pico hydraulics, consumption become energy
}

\author{
Kliton Bylykbashi \\ Sapienza University of Rome, kliton.bylykbashi@uniroma1.it \\ Luca Rubini \\ Sapienza University of Rome, luca.rubini2@uniroma1.it
}

Follow this and additional works at: https://knowledgecenter.ubt-uni.net/conference

Part of the Engineering Commons

\section{Recommended Citation}

Bylykbashi, Kliton and Rubini, Luca, "New configurations of housing facilities developed in height. Pico hydraulics, consumption become energy" (2015). UBT International Conference. 52.

https://knowledgecenter.ubt-uni.net/conference/2015/all-events/52

This Event is brought to you for free and open access by the Publication and Journals at UBT Knowledge Center. It has been accepted for inclusion in UBT International Conference by an authorized administrator of UBT Knowledge Center. For more information, please contact knowledge.center@ubt-uni.net. 


\title{
New configurations of housing facilities developed in height. Pico hydraulics, consumption become energy
}

\author{
Kliton Bylykbashi ${ }^{1}$, Luca Rubini ${ }^{2}$ \\ ${ }^{1}$ Aerospace and Mechanical Engineering Sapienza University of Rome \\ ${ }^{2}$ CIRPS - Interuniversity Research Centre for Sustainable Development, \\ Sapienza University of Rome \\ $\left\{\right.$ kliton.bylykbashi ${ }^{1}$, luca.rubini $\left.{ }^{2}\right\} @$ uniroma1.it
}

\begin{abstract}
The continuous growth of the population and the increasing demand of urbanization expansion towards the development of high-rise buildings.

To meet their energy demand, the European Community is trying to address the designers to nearly zero-energy buildings.

It is reasonably simple to produce a small residence totally energy efficient however it will be a real challenge to do the same for high-rise residential buildings.

In the general research of the " $\mathrm{P}>20$ " a building of more than 20 floors, equipped with renewable energy systems and with low impact technologies, with complete energy efficiency is studied energy self-sufficient. The first technology introduced in this paper will be the Pico Hydraulics system, a technology for the exploitation of hydro electric potential of grey water to produce electricity. Finally, the economic, environmental and social advantages of $\mathrm{P}>20$ is to be illustrated, for Albanian and European cities.
\end{abstract}

\section{Targets of the paper}

A decisive and essential component of policies for sustainable development is represented by the ecological and sustainable building. As a matter of fact, the sustainable future require the construction of smart and ecological buildings.

Starting from 1997 with the COP 3, held in Kyoto, until the present day, a great progres s towards renewable energies and to energy efficiency has been made, ranging between the industrial and the residential sector; for this reason, the Eighth European Framework Programme (Horizon 2020), provides substantial funding for research and innovation, in particular for the reduction of emissions of civil and commercial structures.

The planet's future is increasingly related to the man's ability, to conform his living, to resist the need to damage the environment as little as possible, to consume the least possible of water, soil and energy.

The following paper has the objective to combine a variety of renewable powered sy stems with a mini smart grid, so that they make zero emission (Zerobuild) the high buildings (the so called "P20", i.e. the buildings higher than 20 flats).

In the P20 will be considered the following technologies:

- photovoltaic systems;

- cogeneration and trigeneration systems;

- mini hydraulic systems;

- ultrafiltration systems;

- smart home systems;

- mini smart grid systems.

This paper will describe the mini hydro and Pico Hydraulic technology, and how this system can be a considerable contribution in the projects of new high buildings. 


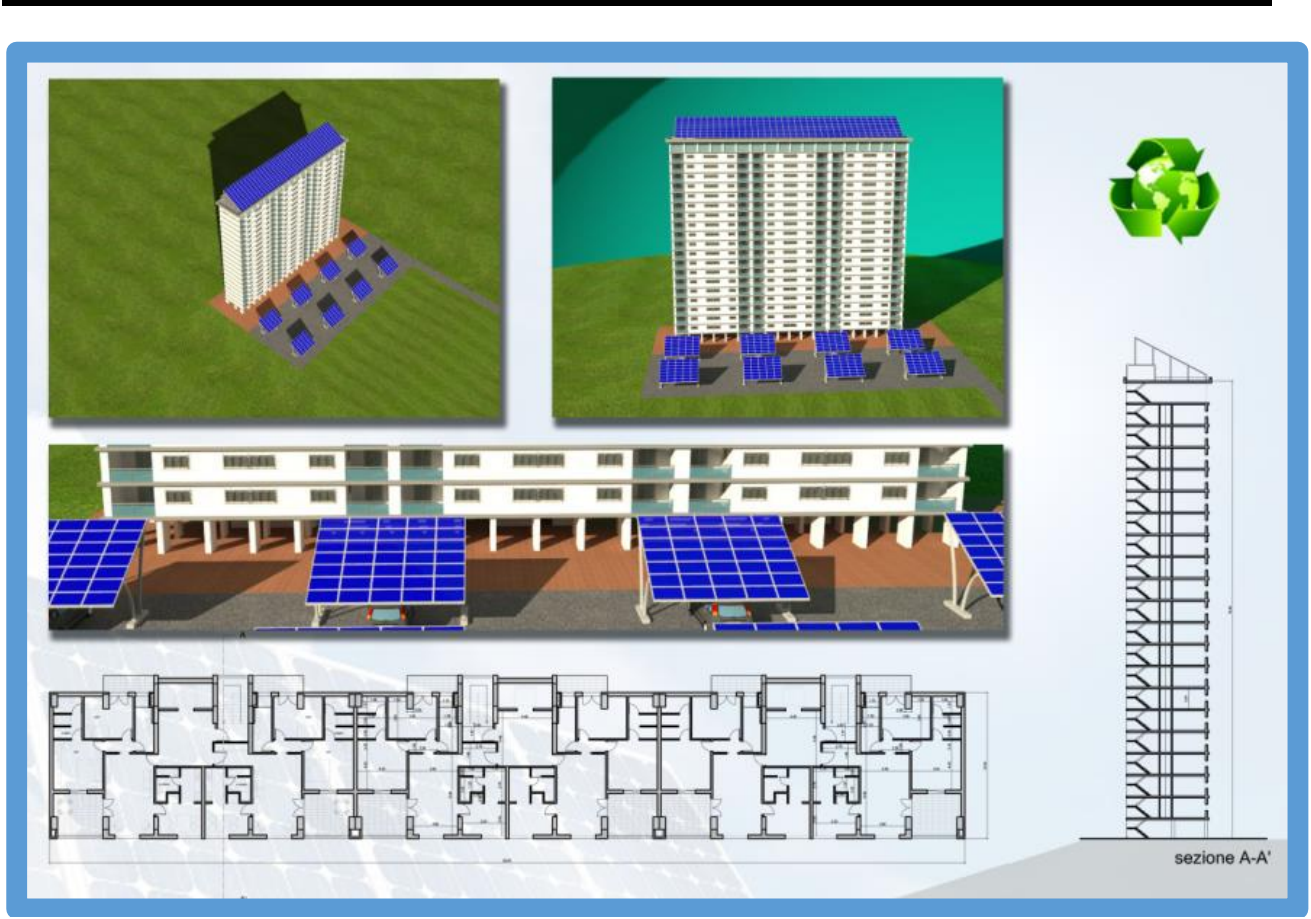

Figura 1. Excellence of Picoidraulica (mini hydraulic system)

Picoidraulica is the new energy transformation system to introduce into P20 buildings; this project aims at reaching the following objectives:

- energy recovery of a building's water supply and reduction in $\mathrm{CO}_{2}$ emissions;

- reduction in primary energy consumption from the grid;

- zero or nearly-zero emission buildings;

- intelligent management of the building's electricity grid;

- an economical(ly) advantageous and efficient project;

- low maintenance costs;

- easy installation and reproducibility of the technology.

Fig. 1 shows how, with hydropower technology, the building takes advantage of the grey water coming from the supply of domestic water, excluding toilets. Pressure tanks to accumulate rainwater and grey water complement the system. These tanks serve two purposes: on the one hand, they assure a stable flow of the filtered water towards the turbines, and on the other hand they act as a buffer storage that can be managed in a way as to supply electricity when the building's demand peaks.

This system provides two major environmental benefits:

1. reduction of $\mathrm{CO}_{2}$ emissions;

2. cleaning of the building's greywater via the filters placed in the storage tanks.

\section{Picoidraulica System in P 20}

Daily, high quantities of water are normally wasted without considering a possible energy -related purpose. Turning the consumers comfort into useful, green energy; with this system, advantage can be taken of the potential energy of the water through an appropriate system for green energy generation. 


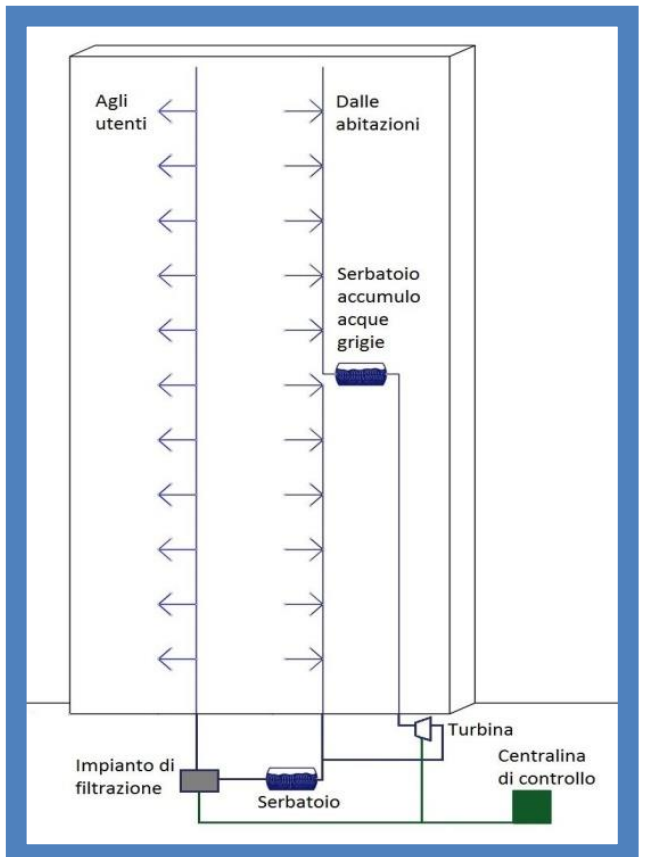

Figura 2. Configuration of Hyraulic Sy stem

The basic idea is to integrate mini Pelton turbines $(2-3 \mathrm{~kW})$ and storage tanks into the building piping plant, in order to keep the flow rate and height constant and therefore avoid problems related to variations of the mechanical stresses in the turbine.

All of these objectives could be reached by extracting the potential energy of the greywater water along the exhaust pipe and convert it into electricity. The water coming from appliances, sinks and showers is in fact, sufficiently "clean" in order to be channelled through a turbine. The only difficulty of the energy system should be the uncertainty regarding the rate at which the water flows down the pipes, or the inconstancy of the hy draulic head due to vary ing heights from which the water originates. The best way to resolve it this would be to position a tank to accumulate the water at an intermediate floor of the building in order to ensure both a constant flow rate and head before entering the turbine. In this way, half of the theoretical potential energy available in this system could be transformed into electrical energy. The higher the buildings the more storage tanks would be installed.

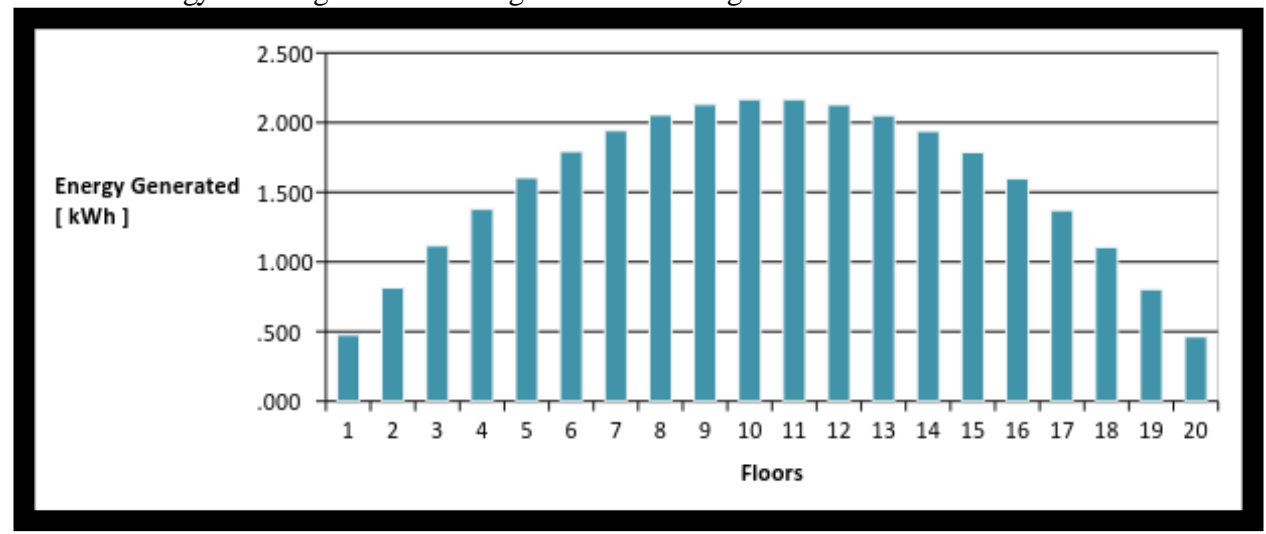

Figura 3. Potential estimate of gray water

This technology would be able to produce more than $10 \mathrm{kWh}$ a day for high buildings (20 floors) and can address other problems that could arise, such as: 
- decreasing the consumption of primary energy;

- creating a smart grid within the building;

- decreasing the emissions of $\mathrm{CO}_{2}$;

- reducing the overall energy consumption of buildings;

- decreasing the country's dependency on fossil fuels;

- improving the waste water quality;

- recy cling of waste water for further use;

- $\quad$ reducing the waste of drinking water (greywater, once purified, may be suitable for second use).

The electric energy generated by using this technology can offset the costs related to communal lighting and auxiliary services like pumps and elevators in the building.

The necessary components for this energy production system are widespread, readily available, low cost, durable and reliable: turbines, tanks, pipes and accessories for the grid connection. The management software, based on the data derived from intelligent control units, that are easily available in the marketplace, needs to be further taken into consideration. Its cost would depend on the size of the building, but has been estimated to be around $1.000-3.000 €$.

If Picoidraulica was installed during the construction of the building, the cost would be considerably less. In Italy the government encourages the micro-hydraulic technology with an all-inclusive rate of $€ 0.257$ for each $\mathrm{kWh}$ of energy produced. Note that a building that produces a daily amount of 10 $\mathrm{kWh}$, would correspond to approximately $3650 \mathrm{kWh}$ annually would generate a related income of $€$ 938 per year, in which case, a payback period of less than three years could be reached.

Using this technology, a new greywater management system would need to be applied in order to filter detergents used for domestic reasons with the systems provided in the storage tanks.

This energy recovery method would create jobs opportunities for the mechanical, the electricity and the chemical engineering industies. Picoidraulica provides in fact combined advantages for the environment, economy and quality of life, whilst creating a building with a green "DNA".

\section{Potential scenarios of Pico hydraulics Sys tem for Italy and possible de velopments in Albania}

In order to evaluate the possible impact of the Picoidraulica in Italy, an analysis on the country's highest structures is performed. Currently at least 69 structures $^{9}$ of over 100 metres in height can be documented nationally that could take advantage of this system. Among those are structures that currently already exist and others that are still under construction.

If the buildings documented in note 1 were equipped with the Picoidraulica sy stem, they would deliver a daily energy amount of $15-50 \mathrm{kWh}$ per building. Assuming an average value of $33 \mathrm{kWh}$ per day per building, these structures would be able to produce approximately $831.1 \mathrm{MWh}$ of clean energy annually. In 2011 "IST AT", the Italian National Institute of Statistics, reported 28,863,604 households in the national territory. Only $12 \%$ reside in a structure of between 12 and 35 storeys.

If equipped with a Picoidraulica system they could produce $12 \mathrm{kWh}$ daily per building on average. As there are about approximately 3,463,632 of these buildings in Italy, they could be able to produce $15,170 \mathrm{GWh}$ annually. Because the energy absorbed by the pumps derives from the grid and is therefore not completely renewable, the system as a whole would not be entirely green. The Picoidraulica system will however contribute to creating a zero emission building where further interventions assure the complete independence from fossil fuels.

In addition to the energy savings a significant reduction in $\mathrm{CO}_{2}$ emissions could be achieved. The Italian national network produces about 0.44 tons of $\mathrm{CO}_{2}$ per $\mathrm{MWh}$ of generated energy, so

\footnotetext{
9 including: "Torre Unicredit", Milano, Lombardia, $231 \mathrm{~m}$ high with 35 floors; "Grattacielo Intesa Sanpaolo", Torino, Piemonte, 167 m high with 39 floors; "Palazzo Lombardia", Milano, Lombardia, 161 m high with 33 floors; "Torre Eurosky", Roma, Lazio, 155 m high with 35 floors; others. There are other structures currently under construction: "Torre Landmark", Rozzano, 212 m with 45 floors; "Grattacielo della Regione Piemonte", Torino, 209 m high with 42 floors; "Torre Isozaki", Milano, 207,20 m high with 50 floors; others.
} 
approximately $6,675,113$ tons of $\mathrm{CO}_{2}$ emissions could be saved in total per year with installing the Picoidraulica systems.

A Tonne of Oil Equivalent, TOE, has an energy amount released by combustion of $42 \mathrm{GJ}$ or 11.63 $\mathrm{MWh}$. The energy content of the potential of the Picoidraulica system application amounts up to approximately $3,261,300.80 \mathrm{TOE}^{10}$ annually. This means that every year there would be savings of around 22,337,676.68 barrels of crude oil ${ }^{11}$. Currently, the barrel has a value of $\$ 49$ (20-10-2015 but it is well known that the price varies continuously), so the barrel is worth $€ 43$. The application of this technology could therefore mean $€ 0.97$ billion $^{12}$ of savings for the Italian economy and ap proximately 10 million tons of $\mathrm{CO}_{2}{ }^{13}$ savings for the environment.

If Italy decides to adopt the Picoidraulica technology saving about $€ 970$ million annually, it could avoid an estimated $€ 19.4$ billion in 20 years.

Albania, a country with strong economic growth, where the annual increase of GDP was more than $6 \%$ average between 2000 and 2009, only in part slowed in recent years from the effects of the global economic crisis (therefore registering a growth of 3\%), visibly an improvement on many European countries (Macroeconomic Analy sis of ISTAT).

Economic growth should unquestionably be accompanied by an environmentally sustainable development, and a similar technology could be a potential solution for the new Albanians scenarios.

\section{Potential scenarios of Pico hydraulics Sys tem for Europe}

The application of the Picoidraulica system would deliver the following results at the European level in countries, for example: Austria (3,589,849 buildings); France (33,049,012 buildings); Great Britain (26,142,857 buildings); Netherlands (16,577,612 buildings); Portugal $(3,436,409$ buildings); Spain (26,768,715 buildings); Switzerland (3,362,112 buildings); Italy (28,863,604 buildings). The total number of buildings in Europe that are considered relevant for the Picoidraulica system is $18,986,169^{14}$; the average energy generated by the Picoidraulica per building is $19 \mathrm{kWh}$, producing a total of $131,669,082 \mathrm{MWh} /$ year.

In order to produce these $131.67 \mathrm{TWh}$ in electricity about $329.173 \mathrm{TWh}$ of thermal energy from the combustion of 193,861,363.21 barrels of crude oil are required. This combustion produces more than 86 million tonnes of $\mathrm{CO}_{2}$ per year ${ }^{15}$. The cost that Europe would save amounts up to about $\$ 8.4$ billion per year, which corresponds to $\$ 167.6$ billion over the next 20 years.

The Picoidraulica would increase job opportunities along its supply chain. Additional job opportunities correspond to economic growth for the European countries that decide to adhere to the development of this building technology. The number of jobs that would be created is around 346,363 for the next 20 years. This business would further foster a market for new organic detergents, which are free of pollutants and safe for the environment.

10 This assumes an electric conversion factor 0.4 , which means an electric energy content of 15.171.541, $3 \mathrm{MWhe}$. This requires approximately 37,928,853.25 MWh thermal, or approximately $3,261,300.80$ TOE per year.

${ }^{11}$ A barrel of crude oil has a weight of about $146 \mathrm{~kg}$.

${ }^{12}$ More precisely $970.583 .666,08 €$.

${ }^{13} 22,337,676.68$ barrels of crude oil would release approximately 9,967,722.34 t of $\mathrm{CO}_{2}$.

${ }^{14}$ The buildings over 12 floors make up $20 \%$ of the total; only $11 \%$ instead correspond to the buildings considered in the project, which have the ability to convert the Picoidraulico daily with an energy of $15-22 \mathrm{kWh}$.

15 More precisely 86.50659 million tonnes of $\mathrm{CO}_{2}$ per year. 


\section{Conclusions}

The Picoidraulica is an innovative project that uses the water supply of greywater to convert its potential energy into electrical energy. The reduction of $\mathrm{CO}_{2}$ emissions and the containment of thermal migration are the benefits that are reaped of the introduction of this technology. The storage tanks equipped with filters solve the problem of the disposal of the wastewater after its life cycle. Picoidraulica systems consume less water and promote a smart management system of power consumption inside residential buildings.

Compared to a photovoltaic system the Picoidraulica achieves good results in buildings that develop vertically. In fact, while a photovoltaic sy stem is developed over a horizontal area, this technology is implemented in height. With the growth of population and vertical structures, this solution can certainly support and at the same time overcome the photovoltaic technology in terms of potential. In addition, the costs of Picoidraulica are contained with $€ 1,000$ up to $€ 5,000$ for buildings over 40 floors. The components of these systems are simple and basic: a Pelton turbine, a generator, an inverter, a regulatory framework or a control unit and a tank with filters, while the ducts and wirings are already found in the buildings.

The two technologies must be combined to create a low energy building, which also produces less $\mathrm{CO}_{2}$. It often happens during periods of time when the solar radiation is maximum that not all the electricity produced is consumed. In this case it would also be possible to accumulate water in the storage tanks in order to convey it into the turbine for the times of a peak energy demand, thus using the system as a type of energy storage. A subsequent application of Picoidraulica systems could be the utilization of the water filtering sy stems, so as to reuse the filtered wastewater for civil purposes, such as the cleaning of buildings and roads, minimizing the wastage of drinking water for these uses.

\section{Bibliography}

1. S. Baeutu, I. Ciongradi, Nonlinear finite element analy sis of reinforced concrete slit walls with Ansys, Faculty of Civil Engineering and Building Services, "Gheorghe Asachi" Technical University of Iasi, 2011

2. Luca Rubini, Silvia Sangiorgio - New Green Building, Rome, Hoepli, 11/2010

3. M. A. Boniforti, Hydraulic implemented, Department of Mechanical and Aerospace Engineering, University of Rome La Sapienza, Unpublished, 2011

4. Luca Rubini, Silvia Sangiorgio - Renewable Energy, Rome, Hoepli, 01/2012

5. Y. A. Cengel, J. M. Cimbala, Mechanics of Fluids, Milan, McGraw-Hill, 2011

6. L. Coppola, Concretum, Milan, McGraw-Hill, 2007

7. S. L. Dixon, C. A. Hall, Fluid Mechanics and Thermodynamics of Turbomachinery, Oxford, Butterworth-Heinemann, 2014

8. C. Arrighetti, R. I. Abenavoli, Lecture Notes of Machines, Department of Mechanical and Aerospace Engineering, University of Rome La Sapienza, Unpublished, 2011

9. R. Gallo, Manual of Industrial Finance, Milano, Giuffrè, 2006

10. M. J. Moran, H. N. Shapiro, D. D. Boettner, M. B. Bailey, Fundamentals of Engineering Thermody namics, Hoboken, Wiley, 2011 